\title{
Palaeopathology of spinal osteophytosis, vertebral ankylosis, ankylosing spondylitis, and vertebral hyperostosis
}

\author{
JULIET ROGERS, IAIN WATT, AND PAUL DIEPPE \\ From the Department of Medicine, Bristol Royal Infirmary
}

SUMMARY Five hundred and sixty intact skeletons and several thousand disarticulated vertebrae have been examined with special reference to spinal fusion. In period they ranged from a 21st dynasty Egyptian mummy to a mid-19th century skeleton. Osteophytes were found in about half of the specimens, as reported previously. Fifteen skeletons with extensive blocks of spinal fusion were also identified. Sacroiliitis was present in two, but the asymmetrical spinal disease and peripheral joint changes suggested Reiter's disease or psoriatic spondylitis rather than ankylosing spondylitis. The remaining 13 had typical features of Forrestier's disease, and extraspinal findings indicative of diffuse idiopathic skeletal hyperostosis (DISH) were also common. A review of the available literature suggests that many palaeopathological specimens previously reported as anklylosing spondylitis are examples of DISH or other seronegative spondylarthropathies. The antiquity and palaeopathology of AS needs reappraisal.

Ankylosing spondylitis is said to be an ancient disease which occurred in animals and man in prehistory. ${ }^{1-5}$ However, it can be difficult to differentiate the osteophytes of spondylosis, vertebral hyperostosis (Forrestier's disease), and ankylosing spondylitis (AS). Zorab ${ }^{6}$ and Bourke ${ }^{7}$ have suggested that descriptions of AS in Egyptian material may have been due to the misdiagnosis of severe osteophytosis.

During recent examinations of skeletal material from this country severe vertebral osteophytosis as well as several cases of probable diffuse idiopathic skeletal hyperostosis (DISH) have been seen, but AS has been absent. ${ }^{8-10}$ We therefore decided to review evidence of spinal osteophytosis (spondylosis), AS, and DISH in a larger selection of palaeopathological material and to review the literature on the antiquity of AS and spinal fusion.

\section{Materials and methods}

A total of 560 adult skeletons with at least part of the vertebral column intact and thousands of disarticulated vertebrae from other skeletons have been

Accepted for publication 5 September 1984 .

Correspondence to Dr P Dieppe, Department of Medicine, Bristol Royal Infirmay, Bristol BS2 8HW. examined. They include one 21st dynasty Egyptian mummy and bones from seven Saxon bishops from Wells Cathedral. Apart from the mummy the earliest is Romano-British and the latest from the mid-nineteenth century, and all were from recently excavated sites in England. These include St Peter's Church, Barton-on-Humber; St Oswald's Priory, Gloucester; Wells Cathedral; and a cemetery in Ilchester in Somerset. Table 1 shows the number of intact skeletons from each period.

After excavation the bones were submitted for anthropological, demographic, palaeopathological (Rogers), radiological (Watt), and rheumatological (Dieppe) assessment. During examination of the vertebral column posterior joints were assessed separately from the changes which occurred at the bony margins. Osteophytes were scored according

Table 1 Numbers of skeletons

\begin{tabular}{lc}
\hline Period & Numbers of skeletons \\
\hline Egyptian mummy 21st Dynasty & 1 \\
Romano-British 1-500 AD & 81 \\
Saxon 700-1100 & 121 \\
Mediaeval 1100-1500 & 303 \\
Post-mediaeval 1500-1850 & 54 \\
Total & 560 \\
\hline
\end{tabular}




\section{Rogers, Watt, Dieppe}

Table 2 Osteophytosis of the spine

\begin{tabular}{ll}
\hline Period & $\%$ Skeletons affected \\
\hline Romano-British & 46 \\
Saxon & 69 \\
Mediaeval & 37 \\
\hline
\end{tabular}

to the standards laid down in the Atlas of Standard Radiographs of Arthritis. ${ }^{11}$ If ankylosis was present between two or more adjacent vertebrae note was made of the distribution of the ankylosed bone on the vertebral body. The number of vertebrae fused, involvement of the posterior joints, involvement of the sacroiliac joints (where possible), and the presence and extent of hyperostosis or arthritis in other parts of the skeleton, including changes at tendon insertions, were also noted.

\section{Results}

IN TACT SKELETONS

As in other recent studies of skeletal material ${ }^{8-10}$ osteophytosis was found to be common, nearly half the skeletons examined having some degree of spinal osteophytosis, often of a massive and exuberant nature (Table 2, Figs. 1, 2). Fusion of osteophytes was seen in only one case. Fifteen other spines with exuberant new bone formation and extensive ankylosis were seen.

Two of these may have been due to a seronegative

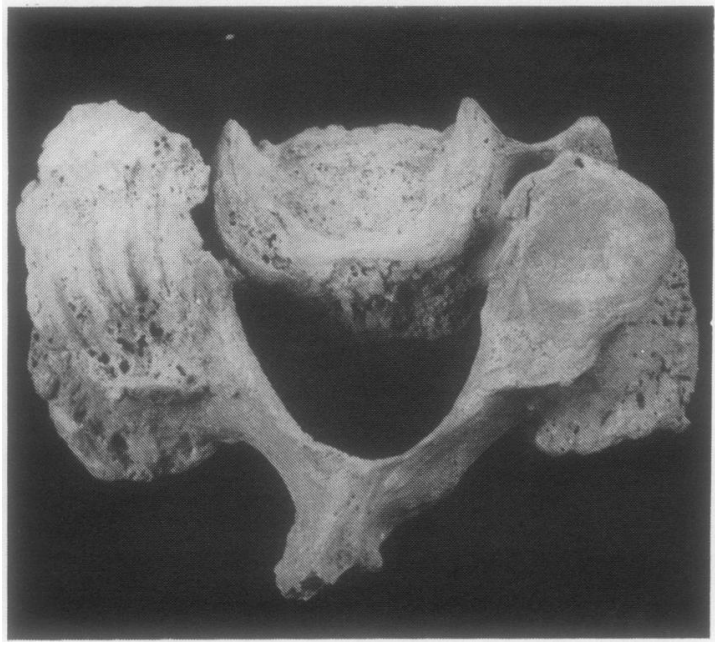

Fig. 1 Superior view of a disarticulated cervical vertebra showing large osteophytes on the margin of the body and extensive osteoarthritis of the right apophyseal joint.

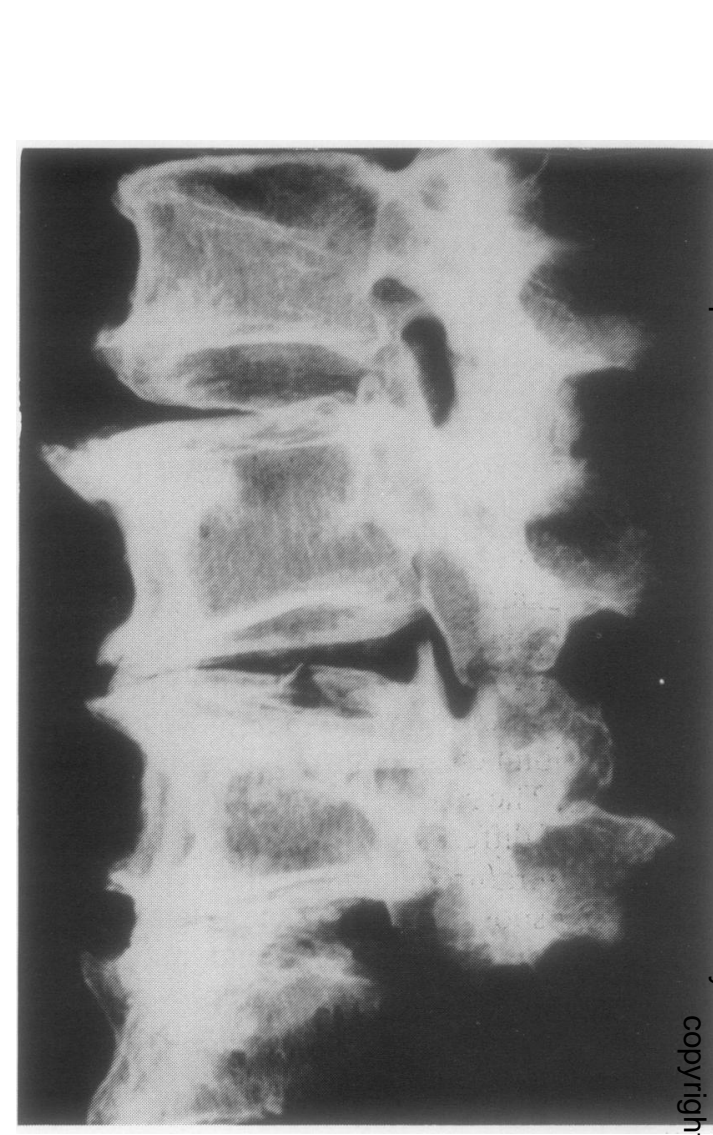

Fig. 2 Radiograph of a section of the lumbar spine from an intact Romano-British skeleton showing typical large, ; horizontal osteophytes originating from the margins of the vertebral bodies.

spondylarthritis. Both cases were associated with an erosive peripheral arthritis in which proliferative erosions, 'cup-and-pencil' deformities, and fusion ofu intertarsal joints were seen. In one the changes in the sacroiliac joints and spine were asymmetrical $\frac{5}{3}$ and in both the vertebral long bridges were more exuberant than expected in ankylosing spondylitis.

Table 3 Prevalence of ankylosing hyperostosis of spine (Forrestier spine) and diffuse idiopathic skeletal hyperostosis (DISH) in different skeletal material

\begin{tabular}{|c|c|c|c|c|c|}
\hline \multirow[t]{2}{*}{ Period } & \multirow{2}{*}{$\begin{array}{l}\text { No. of } \\
\text { skeletons }\end{array}$} & \multicolumn{2}{|c|}{ Forrestier spine } & \multicolumn{2}{|c|}{$D I S H$} \\
\hline & & No. & $\%$ & No. & $\%$ \\
\hline Egyptian & 1 & 1 & 100 & 1 & 100 \\
\hline Romano-British & 81 & 0 & 0 & 0 & 0 \\
\hline Saxon & 121 & 2 & 2 & 2 & 100 \\
\hline Mediaeval & 303 & 8 & $2 \cdot 6$ & 5 & 62 \\
\hline Post-mediaeval & 54 & 2 & 3.7 & 2 & 100 \\
\hline Total & 560 & 13 & $2 \cdot 3$ & 8 & $61 \cdot 5$ \\
\hline
\end{tabular}




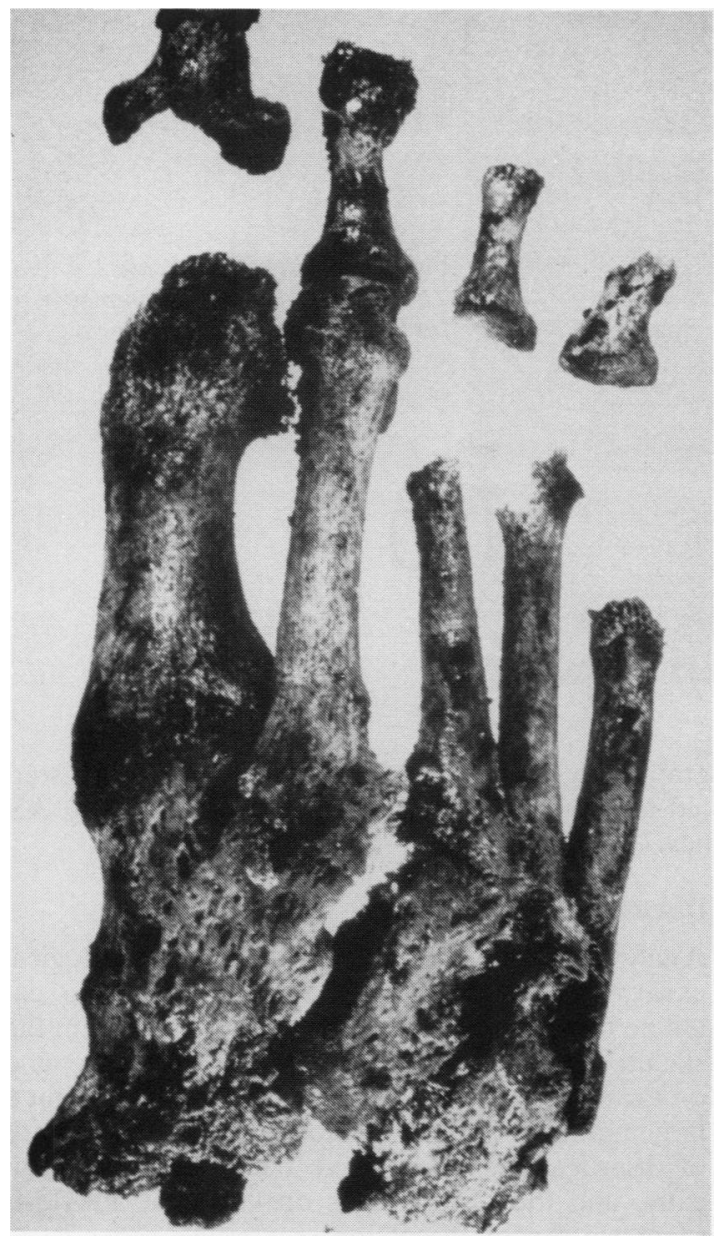

Fig. 3 Photograph of the bones of the forefoot from case 1. Note the fusion of mid-tarsal joints and 'cup-and-pencil' erosion of the interphalangeal joint of the great toe. Other joints in this skeleton showed similar erosive changes, clearly antemortem in origin.

These findings suggest psoriatic arthropathy, or possibly Reiter's disease, rather than AS. ${ }^{12-14}$

The 13 remaining examples of spinal fusion corresponded to the classical descriptions of Forrestier's disease, ${ }^{15} 16$ and many of them also had the extraspinal manifestations as described by Resnick et al. ${ }^{17}$ Table 3 indicates the distribution of Forrestier type spines within the various populations and the percentage of these that also had extraspinal manifestations.

A description of the two possible seronegative spondylarthritides and of four typical examples of DISH is given to demonstrate the features seen in archaeological skeletal material.
Case 1 (Fig. 3).

A 13th century male from Barton-on-Humber, probably over 40 years old. The spine showed marginal lipping of most vertebral bodies with florid spurring and anterior fusion of three blocks, C5-7, T8-12, and L3-5. Peripheral joint changes included ankylosis of the tarsus and carpus and some interphalangeal joints, with pencil and cup erosions of terminal interphalangeal joints in the hand. Other joints affected included the temperomandibular joints, shoulders, and right sacroiliac joints, all of which showed an erosive arthropathy. The left sacroiliac joint appeared normal.

\section{Case 2 (Figs. 4, 5)}

Mediaeval adult male skeleton from Bath Abbey. Axial changes included bilateral ankylosis of the sacroiliac joints and ankylosis of the segment between $\mathrm{T} 7$ and $\mathrm{L} 1$. There was proliferative new bone formation round many segments of the spine, and fusion of the posterior joints from T7 to L5. Spinal syndesmophytes were asymmetrical and predominantly anterior lateral. Peripheral joint changes included moderate osteoarthritic findings of both hips and a proliferative erosive arthropathy of the metacarpophalangeal joint of the left second finger and the carpometacarpal joint of the left thumb.

Case 3 (Fig. 6)

21st Dynasty mummy from Bristol City Museum. Male aged over 50. Combined assessment of spinal radiographs and of the joints (which are still covered in resin-hardened soft tissue) suggested right-sided fusion of T5-7, T8-10, and T10-12, + L4-5. There was definite posterior and inferior calcaneal spurring and a small olecranon spur on the right ulnar.

\section{Case 4}

The Saxon Bishop Giso of Wells Cathedral, died in 1087. A complete male skeleton aged at least 50 . The vertebral column was complete. Fusion occurred between C3 and 4, T3 and 4, and T5-12 inclusive. The ankylosis had the appearance of flowing 'candle wax' down the right hand side. Ossification of costal and thyroid cartilage had also occurred, and there was exostotic spurring at the sacroiliac joints and the iliac crests, ischial tuberosities, and linea aspera, and many of the peripheral joints were surrounded by large osteophytes.

\section{Case 5}

A mediaeval dean from Lichfield Cathedral. Rightsided ankylosis between C7-T1, T7-9, and T9-11. Hyperostotic spurring was found at the ulna, hum- 


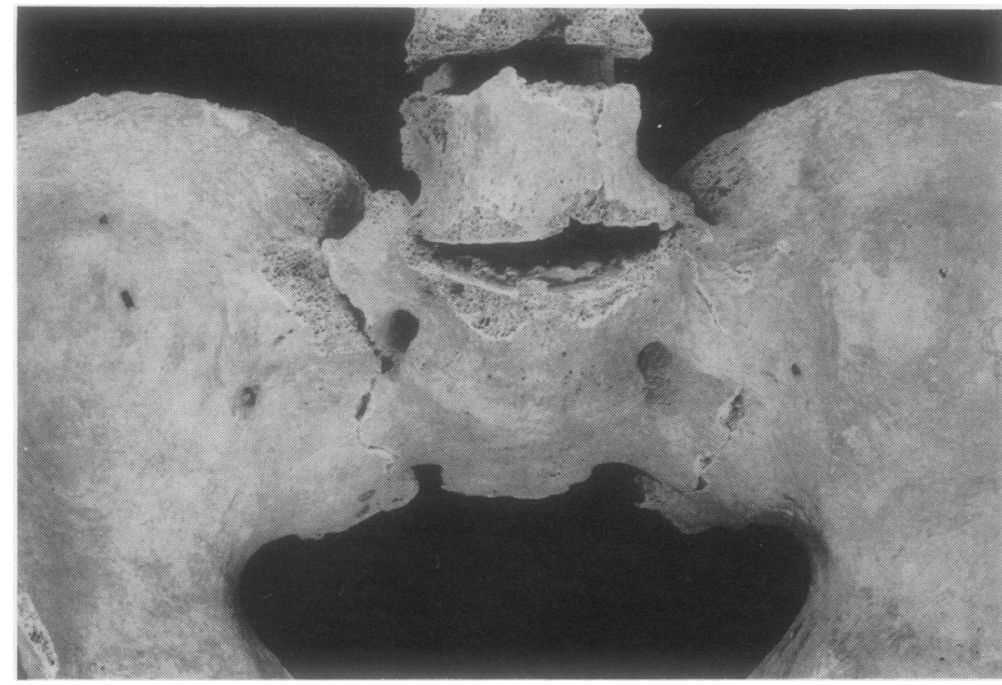

Fig. 4 The pelvis from case 2 . The sacroiliac joints are completely fused, and the pelvis broke away from the sacrum only during excavation of the specimen.

erus, iliac crests, ischial tuberosity, trochanters, linea aspera, tibial tubercles, patella, and calcaneum. Ossification had also taken place in the costal cartilages, and fragments of calcified blood vessels were found with this skeleton.

\section{Case 6 (Fig. 7)}

A 79-year-old woman, early 19th century. Widespread and marked osteophytosis of most joints as well as new bone formation at all the sites mentioned in the previous skeleton. Fusion, again right-sided, had occurred from T4 to L2. L3, although bearing a large bulbous excrescence of bone on the superior right margin, had not yet fused.

In spines 3-6 there was no apparent involvement of the apophyseal joints nor any erosive disease of the sacroiliac joints. In some of the sacroiliac joints of skeletons showing Forrestier's disease there was some ankylosis, but in the superior part only, and it had the appearance of smooth exuberant bone growth as seen on the vertebrae.

\section{DISARTICULATED VERTEBRAE}

During archaeological excavations many separate disarticulated bones are recovered without knowledge of their skeletal origin. Thousands of such vertebrae and several pelvic bones have been seen. Typical osteophytes were very common on these samples (Figs. 1,2), but in a few of them vertical ossification originating from the body of the vertebra was seen, suggesting the early lesion of DISH described by Fournasier et al. ${ }^{17}$ One fused pair of vertebrae was seen in which the visual and radio- graphic evidence of old erosive changes suggested $\frac{\mathbb{D}}{\mathrm{O}}$ old tuberculosis (Fig. 8). No lesions suggesting AS have been observed.

\section{Discussion}

Analysis of skeletal material from archaeologicâㅁำ excavation presents a unique opportunity to ex-s amine the complete spectrum of bony change in the skeleton. Obviously the skeletons examined depenff on availability and may not be representative, but $\$$ large number $(560)$ of skeletons as well as thousands of disarticulated bones have been looked at criti $\frac{0}{3}$ cally, and the observations on vertebral ankylosis seem worthy of discussion.

The main problem encountered is that of diagnos tic criteria: for example, when does severeo osteophytosis which becomes ankylosed cease to be spondylosis and become ankylosing vertebra? hyperostosis? ${ }^{141819}$ For the purpose of this studye we took a vertebral osteophyte to be a bony? protrusion from the cortex of the vertebra appearing at the junction of the vertebral body and thes intervertebral disc. This new bone pointed sideways. and was unlike the vertical ossification of Forrest tier's disease, which had a 'dripping wax' appear ${ }^{\circ}$ ance, was predominantly on the right anterolaterab part of the vertebra, and arose from the body, well away from the disc junction.

Vertebral osteophytes, typical of the type seen in disc disease and spondylosis, were by far the commonest finding in our study. This was also the case in other recent surveys of archaeologicato specimens. $^{8-10}$ Osteophytes are found in skeletaP material from all historical periods ${ }^{20}$ and from many? 
different geographical sites. ${ }^{7}$ Vertebral osteophytes are well known to palaeopathologists and have been used to age skeletons ${ }^{21}$ or to aid interpretation of the possible habits of our ancestors. ${ }^{9}$

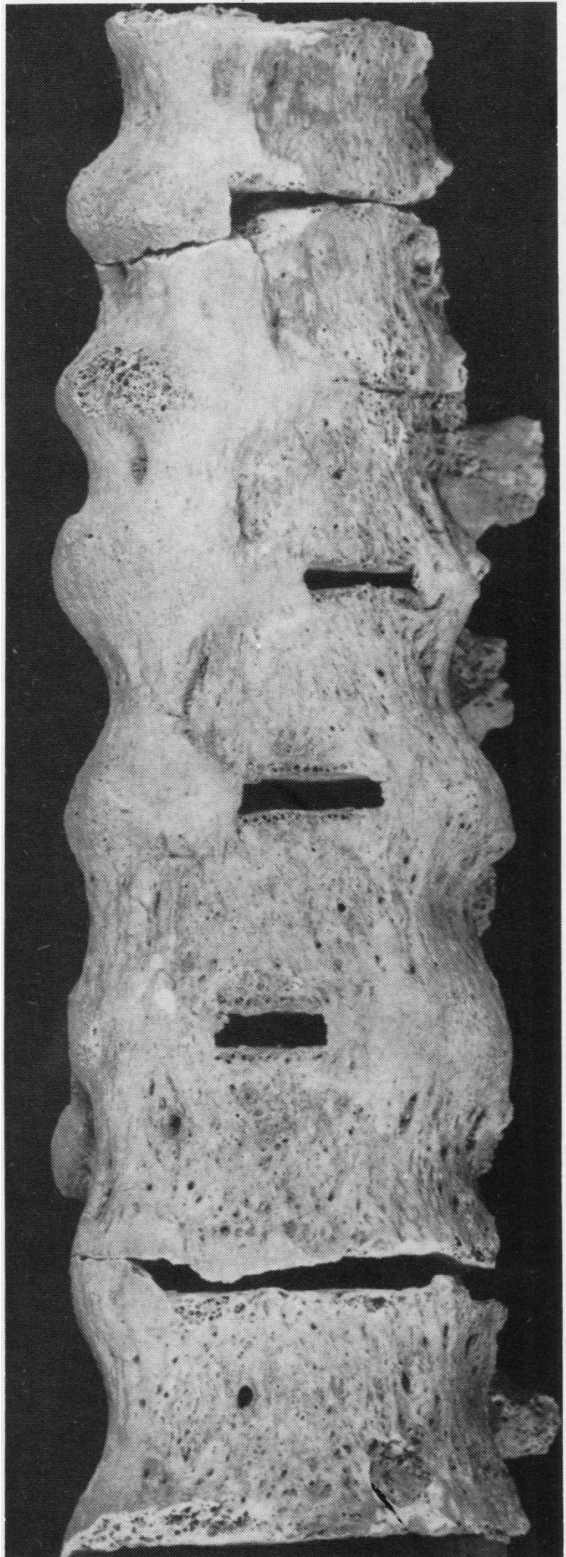

Fig. 5 Part of the thoracolumbar spine from case 2. Note the asymmetrical bony fusion and exuberant calcification. The lower lumbar sections were not affected ('skip lesions') and the overall picture, including hypertrophic peripheral joint erosions, suggests the spondylitis of Reiter's disease or psoriatic arthropathy.

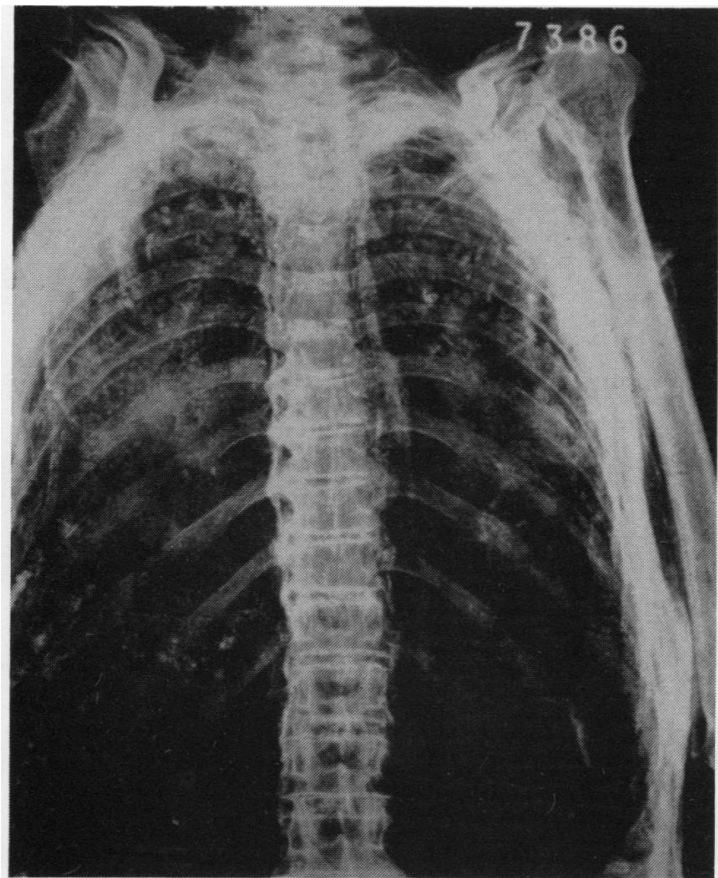

Fig. 6 Chest radiograph of case 3: The Bristol mummy. Note the right sided exuberant osteophytes with fusion, suggesting Forrestier's disease. Typical spurs were seen in other parts of the skeleton.

In 13 of our skeletons and many separate vertebrae the large flowing osteophytes found in the absence of posterior joint changes of erosions of the sacroiliac joints were thought to be typical of Forrestier's disease. ${ }^{14} 18$ This was supported by the finding of extraspinal new bone formation in many cases, and the fusion of blocks of at least four vertebrae in the complete skeletons.

We found DISH in $2.3 \%$ of the adult skeletons examined, varying from $2 \%$ to $3.7 \%$ according to period. This is similar to the rate of $3.8 \%$ for males and $2.6 \%$ for females found by Julkunen et al. ${ }^{22}$ in a contemporary study in Finland. In considering the incidence of DISH in earlier populations it must be noted that contemporary Forrestier's disease has not been found in persons under the age of 40 . The number of people surviving to that age was considerably less in earlier populations than now, so the fact that the incidence is similar was surprising. Although we do not know the origin of all the skeletons with DISH, many of them are definitely from higher social backgrounds---for example, the Egyptian mummy (a priest), a Saxon bishop, and a mediaeval dean. Their standard of living and nutrition was probably better than that of the general 
population, and they probably lived longer. Obesity and diabetes have been noted in association with $\mathrm{DISH}^{23}{ }^{24}$ and may also have been present in these people.

The high incidence of severe osteophytosis and DISH in this and other recent surveys of archaeological material, ${ }^{8-10}$ without there being any examples of ankylosing spondylitis, must raise doubts about

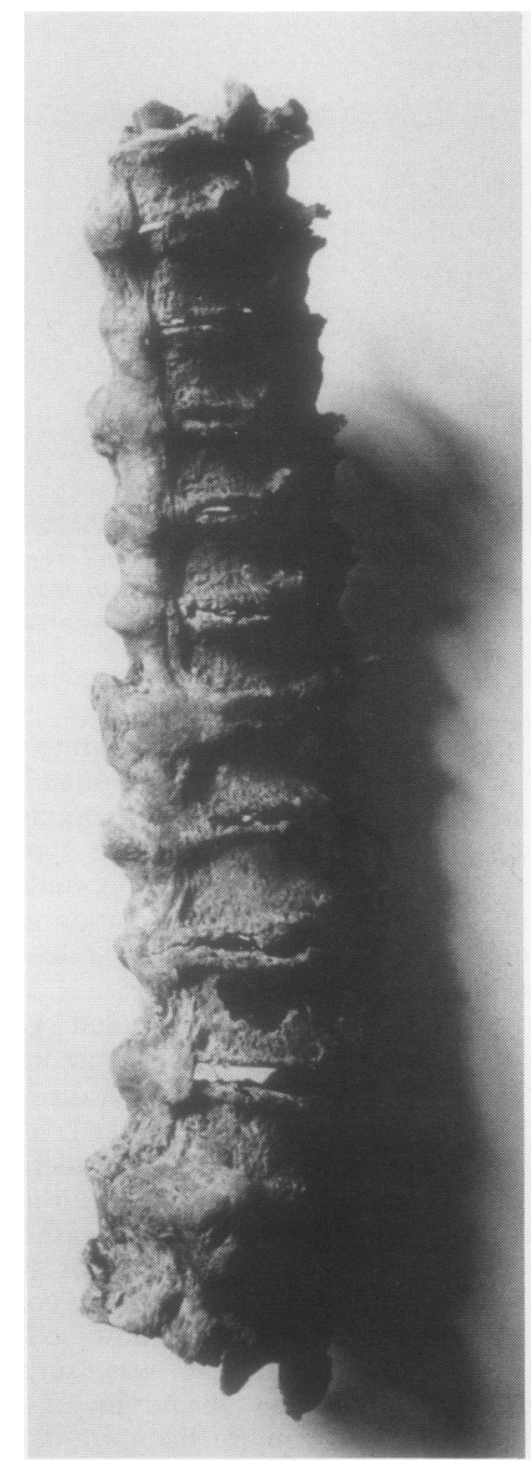

Fig. 7 A section of thoracolumbar spine from case 6. The typical exuberant, right-sided anteriolateral, 'dripping wax' (osteophytes of Forrestier's disease (DISH) have caused fusion of this large segment. previous reports of frequent AS in skeletal material. DISH has been recognised only relatively recently and is not mentioned in contemporary palaeopathological texts. ${ }^{1925}$ It can cause fusion of the upper( third of the sacroiliac joints ${ }^{26}$ and causes confusiono with AS in medicine today. ${ }^{27}$ We have therefore examined previous reports of AS in the $\frac{\bar{p}}{\bar{\alpha}}$ palaeopathological literature.

Many Egyptian skeletons, ranging in date from $3000 \mathrm{BC}$ to the beginning of the Christian era, were examined by Ruffer and Rietti and others. ${ }^{1-4}$ They. described 'ankylosing spondylitis' or 'spondylitis $\vec{\omega}$ deformans' in many cases, but the terms are noto clearly defined. Sacroiliac changes were often ignored or absent, and the spinal changes described included asymmetrical fusion with 'roughness of bones' elsewhere. Nubian skeletons examined by? Smith and Wood Jones were also said to show $\vec{\omega}$ frequent spinal fusion. ${ }^{28}$ Salib describes frequento 'spondylitis' and spinal 'arthritis deformans' in Egyptian material $^{29}$ and Shore states ${ }^{30}$ that spinal 7 fusion was seen in 7 of 274 vertebral columns fromo Ancient Egypt, although he concluded that infection was the most likely cause. Bourke also looked at Egyptian and Nubian material and reported some $\overrightarrow{0}$ possible cases of ankylosing spondylitis. ${ }^{7}$ Howeve only one case is convincing, and in others the asymmetrical changes with large paraverteblo osteophytosis suggest possible DISH. Zorab ${ }^{6}$ was unable to find convincing evidence of AS in Egyptian material and thought that the previous authors $\frac{}{\varnothing}$ had misdiagnosed osteophytosis. It is of interest, therefore, that the only mummy we have been able $\overrightarrow{\vec{B}}$ to look at had clear evidence of mild DISH.

There are surprisingly few convincing descriptions of AS in other palaeopathological literature. $A+$ possible French case from the neolithic period was described by Snorrason; ${ }^{31}$ Morse $^{32}$ and Kidd ${ }^{33}$ have $\frac{0}{-}$ both examined suspected cases from ancient 3 Midwestern skeletons; Zivanovic records a case of mediaeval Anglo-Saxon origin with probable $\mathrm{AS}^{34} \mathrm{O}$ (although he diagnosed rheumatoid arthritis); and 0 Kramar gave a detailed description of a very convincing case from mediaeval Geneva. ${ }^{35}$ Calvino Wells describes many examples of spinal fusion from Anglo-Saxon skeletons; in many of these cases $\widetilde{N}$ DISH seems the likely diagnosis. ${ }^{20}{ }^{36}$ In an excellent $N$ recent monograph Steinbock suggests that about $30 \mathrm{~N}$ cases of possible AS can be found in the ${ }^{\omega}$ palaeopathology literature, and adds two examples? of his own. ${ }^{37}$ One of these has widespread ankylosis? of peripheral as well as spinal joints. It is apparent $\cong$ from examining this literature that most authors, with the notable exception of $\mathrm{Kramar}^{35}$ were not aware of DISH or of other possible causes of spinal $\vec{D}$ fusion such as fluorosis or psoriatic spondylitis. 


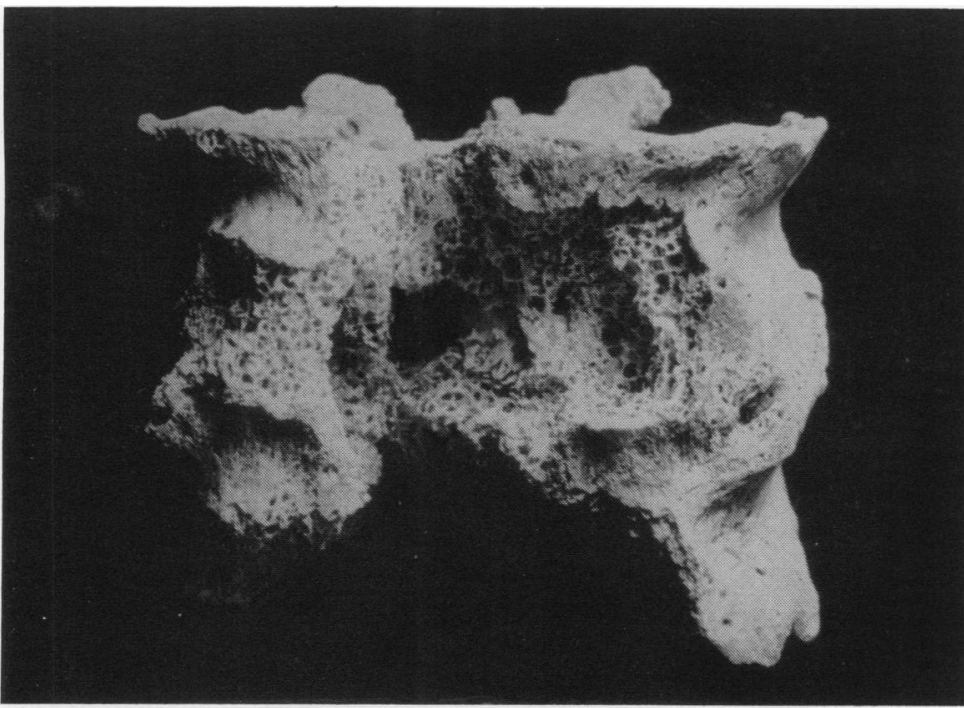

Fig. 8 Part of two disarticulated but fused vertebrae found during excavation. The vertebrae are viewed from the front and show an area of extensive antemortem erosion around the fusion, affecting both bones. It is possible that these changes were caused by tuberculosis.

Most authorities credit Bernard Connor (1691) with the first good pathological description of AS. ${ }^{38}$ Several good descriptions followed, and, as O'Connell points out, the eponymous work of Bechterew (1892-9), Marie (1898) and Strumpell (1897) came much later. ${ }^{39}$ In view of the striking nature of the disease it is perhaps surprising that there are no good medical descriptions before Connor's work. ${ }^{40}$

The subtle differentiation between AS and the spondylitis of psoriasis or Reiter's syndrome is not mentioned in previous palaeopathological literature. Although it is difficult to be certain on the evidence of old skeletons alone, our two cases with evidence of a seronegative spondylarthritis seem much more compatible with a diagnosis of psoriatic arthropathy or Reiter's disease than simple AS. ${ }^{12-14}$ It is impossible to discover whether other skeletons described in the palaeopathology literature had these diseases because of the poor quality of the descriptions and illustrations. However, psoriasis was probably common in our ancestors, and we have seen other skeletons with peripheral joint changes indicating psoriatic arthropathy (Rogers $\mathrm{J}$ et al., in preparation). It is certainly surprising that a condition with a prevalence today of nearly $1 \%^{41}$ has not been seen in large surveys of skeletal material which have the discrimination to pick up casês of DISH, spinal TB, and possible psoriatic arthropathy.

\section{CONCLUSIONS}

The very high incidence of AS previously reported in early skeletal populations was not found in our study. DISH was certainly as common in our ancestors as it is now, and may have been mistaken for AS by other palaeopathologists. The presumed antiquity of AS requires critical reappraisal. It is possible that AS, like rheumatoid arthritis, might be of recent origin, ${ }^{42}$ although there are a few convincing cases of some type of seronegative spondylarthritis in ancient skeletons. Bywaters dismisses palaeopathological data on disease history as unreliable. ${ }^{40}$ We would argue that critical appraisal of the findings may help establish the antiquity of many bone and joint diseases; in the case of AS, however, the previous descriptions of a high frequency in many ancient skeletons do indeed seem unreliable.

We are grateful to the Arthritis and Rheumatism Council, the Science and Engineering Research Council, and A H Robins Co. Ltd, for financial support.

\section{References}

1 Ruffer M A, Rietti A. On osseous lesions in Ancient Egyptians. J Pathol Bacteriol 1912; 16: 439-47.

2 Ruffer M A. Arthritis deformans and spondylitis in Ancient Egypt. J Pathol Bacteriol 1918; 22: 152-9.

3 Ruffer M A. In: Moodie R L, ed. Studies in the paleopathology of Egypt. Chicago: University of Chicago Press, 1921: 187-201.

4 Moodie R L. Paleopathology: an introduction to the study of ancient evidence of disease. Urbana: University of Illinois Press, 1923.

5 Calin A. In: Kelley W N, Harris E D. Ruddy S, Sledge C B, eds. Textbook of rheumatology. Philadelphia: Saunders, 1981.

6 Zorab P A. The historical and prehistorical background to ankylosing spondylitis. Proc $R$ Soc Med 1961; 54: 415-20.

7 Bourke J B. A review of paleopathology of arthritic disease. In: Brothwell D, Sandison A T, eds. Diseases in antiquity. Springfield: Thomas, 1967: 352-70. 
8 Rogers J, Watt I, Dieppe P. Arthritis in Saxon and mediaeval skeletons. Br Med J 1981; 283: 1668-71.

9 Clarke G A, Delmond J A. Vertebral osteophytosis in Dickson Mound populations: a biomechanical interpretation. Henry Ford Hosp Med J 1979; 27: 54-8.

10 Thould A K, Thould B T. Arthritis in Roman Britain. Br Med J 1983; 287: 24-31.

11 Department of Rheumatology and Medicine, University of Manchester. The epidemiology of chronic rheumatism: atlas of standard radiographs. Oxford: Blackwell, 1961: 2.

12 McEwen C, De Tata D, Lingg C, Porrini A, Good A, Rankin J. Ankylosing spondylitis accompanying ulcerative colitis, regional enteritis, psoriasis and Reiter's disease. Arthritis Rheum 1971; 14: 291-318.

13 Wright V. Psoriatic arthritis. In: Kelley W N, Harris E D, Ruddy S, Sledge C B, eds. Textbook of rheumatology. Philadelphia: Saunders, 1981.

14 Resnick D, Niwayama G. Radiographic and pathologic features of spinal involvement in diffuse idiopathic skeletal hyperostosis (DISH). Radiology 1976; 119: 559-68.

15 Forrestier J, Rotes-Querol J. Senile ankylosing hyperostosis of the spine. Ann Rheum Dis 1950; 9: 321-30.

16 Forrestier J, Lagier R. Ankylosing hyperostosis of the spine. Clin Orthop 1971; 74: 65-83.

17 Resnick D, Shaul S R, Robins J M. Diffuse idiopathic skeletal hyperostosis (DISH). Forrestier's disease with extraspinal manifestations. Radiology 1975; 115: 513-24.

18 Fournasier V L, Littlejohn G, Vrowitz M B, Keystone E C. Smythe H A. Spinal entheseal new bone formation: the early changes of spinal diffuse idiopathic skeletal hyperostosis. $J$ Rheumatol 1983; 10: 939-47.

19 Ortner D J, Putschar W G J. Identification of pathological conditions in human skeletal remains. Washington: Smithsonian Institution, 1981.

20 Wells C. Romano-British cemeteries at Cirencester. Cirencester Excavation Committee: 1982

21 Stewart T D. The rate of development of vertebral hypertrophic arthritis and its utility in age estimation. Am J Phys Anthropol 1957; 15: 433-49.

22 Julkunen $\mathbf{H}$, Hanonen O P, Pyorala K. Hyperostosis of the spine in an adult population. Ann Rheum Dis 1971; 30: 605-12.

23 Harris J, Carter A R, Glick E N, et al. Ankylosing hyperostosis. I. Clinical and radiological features. Ann Rheum Dis 1974; 33: 210-5.
24 Julkunen H, Pyorala K, Lehtaurirta E. Hyperostosis of the spine in relation to age and hyperglycaemia in men aged 30-69. Ann Med Intern Fenn 1968; 57: 1-7.

25 Steinbock R T. Paleopathological diagnosis and interpretation. Springfield: Thomas, 1976

26 Brigode M, Francois R J, Dory M A. Radiological study of the sacroiliac joints in vertebral ankylosing hyperostosis. Ann $\bar{O}$ Rheum Dis 1982; 41: 225-31.

27 Yagan R, Khan M A. Confusion of roentgenographic differen- $-\frac{\mathscr{S}}{\partial}$ tial diagnosis between ankylosing hyperostosis (Forrestier's disease) and ankylosing spondylitis. Clin Rheumatol 1983; 2: ఎ 285-92.

28 Smith G E, Wood Jones F. Archaeological survey of Nubia. $\overrightarrow{0}$ Report for 1907-1908. Cairo: National Print Department, 1910: 2: 273.

29 Salib P. Orthopaedic and traumatic skeletal lesions in anciento Egyptians. J Bone Joint Surg 1962; 44B: 944-7.

30 Shore L R. Some examples of disease of the vertebral columno found in skeletons of ancient Egypt. A contribution to paleopathology. Br J Surg 1936; 24: 256-71.

31 Snorrason E S. Rheumatism past and present. Can Med Assoc 1942; 46: 589-94.

32 Morse D. Ancient disease in the Midwest. Illinois State Mus Rep Invest No. 15, 1969.

33 Kidd K E. A note on the paleopathology of Ontario. Am J Phys_Anthropol 1954; 12: 610-5.

34 Zivanovic S. Ancient diseases: the elements of paleopathology. (D) London: Methuen, 1982.

35 Kramar C. A case of ankylosing spondylitis in mediaevalo Geneva. OSSA 1982; 8: 115-29.

36 Wells C. Joint pathology in ancient Anglo-Saxons. J Bone Joint $\vec{\varphi}$ Surg 1962; 44B: 948-9.

37 Steinbach H L, Feldman R, Goldberg M B. Acromege Radiology 1959; 72: 535-48. 38 Connor B. Thesis, Rheums. Philos Trans $R$ Soc Lond 16943;
19: 21 .

39 O'Connell D. Ankylosing spondylitis: the literature to the close⿳亠二口 of the nineteenth century. Ann Rheum Dis 1956; 15: 119-23.

40 Bywaters E G L. In: Moll J H M, ed. Ankylosing spondylitis. Ф London and Edinburgh: Churchill Livingstone, 1983.

41 Lawrence J S. Rheumatism in populations. London: Heine $\overline{\bar{B}}$ mann, 1977.

42 Buchanan W W, Murdoch R M. Hypothesis that rheumatoidarthritis will disappear. J Rheumatol 1979; 6: 324-9. 